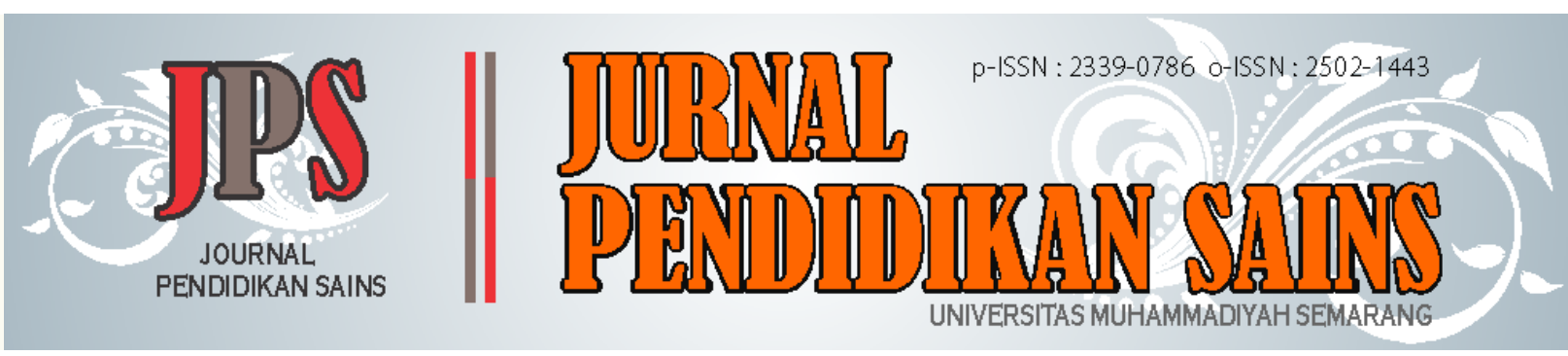

\title{
Needs Analysis of Problem Solving Based Learning Video Development to Train Students' Concept Understanding
}

\author{
Yenni Lestari $^{\text {a,1,*}}$, M. Rahmad ${ }^{\text {b,2 }}$, Zulfarina ${ }^{\text {b,3 }}$ \\ ${ }^{a}$ Yenni Lestari, Jalan Balam Sakti, Pekanbaru and 28293, Indonesia \\ ${ }^{\mathrm{b}}$ M. Rahmad, Jalan Citra Raya, Pekanbaru and 28293, Indonesia \\ ${ }^{\mathrm{c}}$ Zulfarina, Jalan Melur, Pekanbaru and 28289, Indonesia \\ ${ }^{1}$ Yennilestari5@gmail.com*; ${ }^{2}$ m.rahmad@lecturer.unri.ac.id; ${ }^{3}$ zulfarin@yahoo.co.id
}

\begin{tabular}{ll}
\hline \multicolumn{2}{l}{ Article history } \\
\hline Submission & $:$ 2021-02-27 \\
Revised & $: 2021-03-29$ \\
Accepted & $: 2021-04-18$
\end{tabular}

Keyword

Need analysis

Learning video

Problem-solving

Concept understanding

\begin{abstract}
Students' understanding of concepts is an essential factor in the success of learning. However, in reality, Indonesian students' conceptual understanding is still low. The common understanding of students' concepts is because students are not actively involved in problem-solving activities. Student involvement can be trained by using one of the communication tools in the form of exciting learning videos to get students' attention in learning activities. This research is survey research as a first step in developing problem-solving learning videos. The benefit of this research is to find out what students currently need in science learning and how much students need to develop problem-solving-based learning videos. The subjects used in this study were junior high school students with a total sample of 48 students and ten science subject teachers selected based on an area. This needs analysis includes four indicators, namely a) analysis of learning problems; b) analysis of learners; c) analysis of objectives; d) analysis of settings. Based on the results of this study, information was obtained that the development of problem-solving-based learning videos needed to be developed as a science learning media to train students' conceptual understanding in the city of Pekanbaru.
\end{abstract}

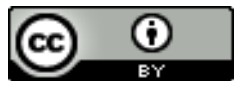

This work is licensed under

a Creative Commons Attribution 4.0 International License (C)2021 Jurnal Pendidikan Sains Universitas Muhammadiyah Semarang

\section{INTRODUCTION}

Science learning achievement in Indonesia is still low. This can be seen from the Program for International Student Assessment (PISA) results in 2018. The science learning achievement score of Indonesian students only 396 points, with 71 out of 79 countries (Yuli Belfali, 2019). The Trends International Mathematics and Science Study (TIMSS) survey in 2015 also showed the same thing. Indonesian students' average science achievement score was only 44 out of 49 participating countries, and the average score was 397 (Nizam, 2016). These data indicate that the conceptual understanding of each student is shallow. One of the common understandings of students' concepcommonis is the lack of active student contributions in finding and solving the learned concepts (Azizah et al., 2015).

Students have difficulty solving problems to get a concept (Sadiqin et al., 2017). Students tend to memorize and remember the teacher's explanation of a concept without deep understanding. Even though https://jurnal.unimus.ac.id/index.php/JPKIMIA/index 
knowledge should not be acquired passively by students, it is actively built by students themselves. Students are actively involved in continuously constructing knowledge so that the concept changes to a more complex direction (Richards, 2020).

One of the efforts to increase student involvement in the learning process is to use various learning models. There are several problem-based learning models, one of which is the problem-solving model (Sadiqin et al., 2017). Problem-solving is a model that exposes students to a problem that must be solved, meaning that students are given a problem to find a solution to find knowledge (Fitria et al., 2017; Ozturk \& Guven, 2016; Sadiqin et al., 2017). Problem-solving models have a close relationship with conceptual understanding (Whyte, 2017). Strengthened by Balta et al. (2016), Sadiqin et al. (2017), Jackson \& Martin (2014), problem-solving is a learning model that is suitable for helping students to practice or improve understanding of concepts.

Furthermore, student involvement in the science learning process can be trained using learning media. Innovative and creative teachers must develop learning media in line with developments in science and technology. Learning media is a means or instrument that encourages the effectiveness and efficiency of learning activities (Haryadi et al., 2019; Widodo \& Wahyudin, 2018). One effective learning media to train students' understanding of concepts used by teachers in the science learning process is video media (Istiqomah et al., 2017; Yulisa et al., 2020).

Video learning media is one of the learning media in the form of images that can move and are equipped with sound to facilitate information delivery (Pradipta et al., 2016). Video is an audio-visual learning media that combines visual material and additive material. Visual material makes students able to capture learning messages through visualization (observation), and auditive material makes students able to receive messages through hearing (Busyaeri et al., 2016).

Videos have been exploited frequently to improve teaching and learning (Khairani et al., 2019). Orcos Palma et al. (2018) disclosing video is one of the learning media (technology that involves sound, image, and video), which has become a trend for millennials in the 21 st century. The ability of video to display images and sound simultaneously with its high level of clarity provides its advantages as a learning medium (Ljubojevic et al., 2014). Therefore, videos can quickly lead students to understand the material to understand better science learning (Busyaeri et al., 2016).

Another advantage of video is that it can create learning independence, display something detailed and complex, be repeated, slow down, even enlarged, and compare two or more scenes simultaneously (Chen \& Wu, 2015). Videos can also show too small, too big, dangerous, or even that students cannot find directly so that the learning video can explain abstract explanations (Giannakos et al., 2015). This advantage attracts students; learning becomes more concrete, not monotonous, not dull (Nurdin et al., 2019).

Through the video, the teacher can also insert material given to students (Woolfitt, 2015). However, a good video is not just material. Videos should contain content that can lead students to construct their knowledge through problem-solving (Zain et al., 2012). So that the learning carried out is more meaningful and provides direct experience to students.

Based on the advantages and success of using video as a medium in learning and the importance of a learning model, students are actively involved in solving problems. So problem-solving-based learning videos need to be developed in science learning. However, to assess the needs of the video, an initial analysis must be carried out. Assessing the need in developing a learning media is very important because, through this assessment, a media that is suitable for the situation and characteristics of students is obtained. Needs analysis can be done if the learning program designer can carry out a series of analyses related to students' and teachers' needs. The needs analysis in question is (1) analysis of learning problems; (2) student analysis (audience analysis) ; (3) analysis of learning objectives; and (4) analysis of learning settings (Tageh \& Made, 2014).

\section{METHOD}

This type of research is survey research carried out by taking information or data directly on the research subject. The sampling technique used in this research was cluster sampling involving 48 junior high school students and ten teachers of MGMP science subjects in an area. Population determination is carried out based on a predetermined population area. This research procedure can be seen through the scheme shown in Figure 1 below: 


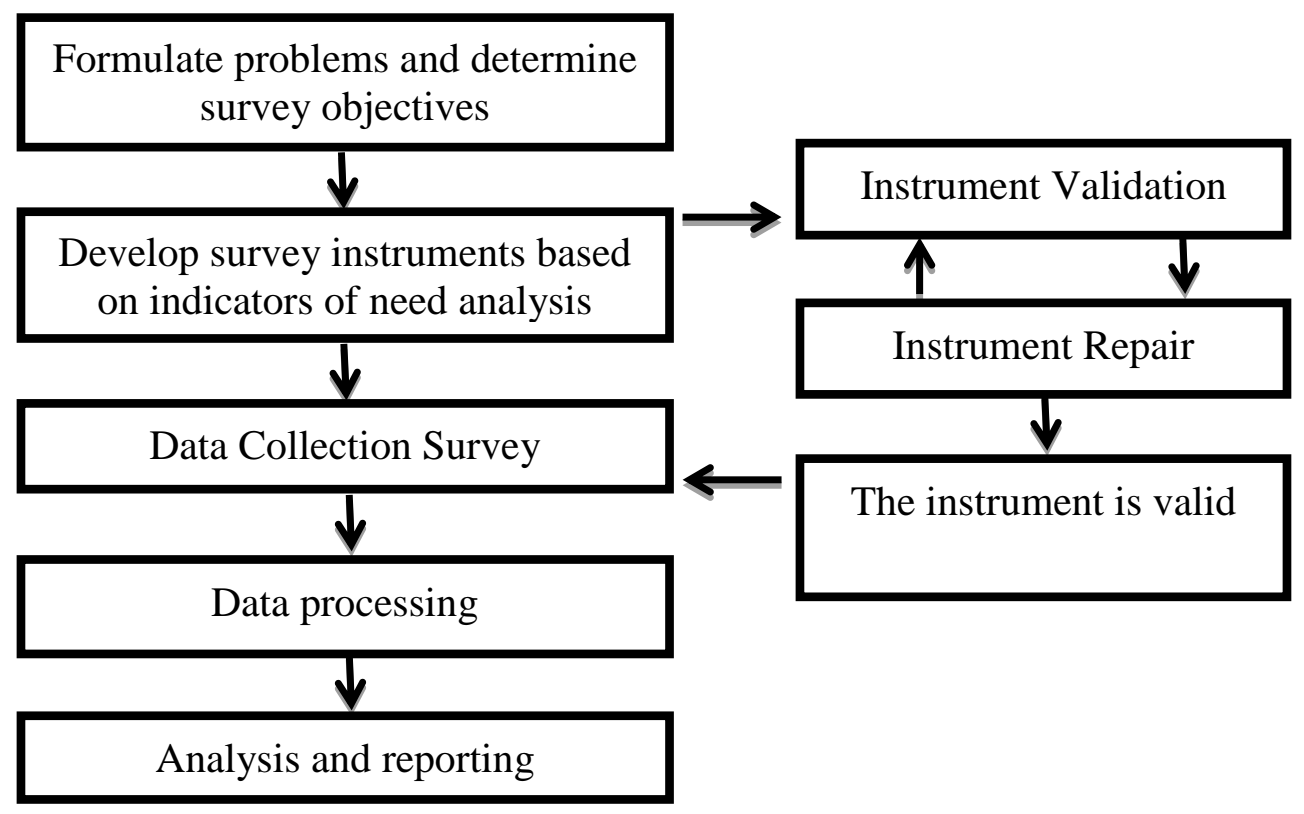

Figure 1. Research Flow

The research instrument used in this research was a closed questionnaire developed based on indicators of learning needs analysis. The questionnaire developed consisted of 16 question items for students and 17 question items for teachers based on four indicators. The number of items for each indicator for the student and teacher questionnaire can be seen in Table 1.

Table 1. Student ad Teacher Needs Questionnaire Indicators

\begin{tabular}{lcc}
\hline Indicators of Need Analysis & $\begin{array}{c}\text { Number of Questions Item } \\
\text { (Students) }\end{array}$ & $\begin{array}{c}\text { Number of Questions } \\
\text { Item } \\
\text { (Teacher) }\end{array}$ \\
\hline Analysis of learning problems & 8 & 10 \\
\hline Analysis of the objective & 3 & 2 \\
\hline Student Analysis & 3 & 3 \\
\hline Analysis of learning settings & 2 & 2 \\
\hline Sumber : (Tageh \& Made, 2014) & &
\end{tabular}

Table 1 was made of 4 choices, namely the score strongly agree 4 , agree score 3 , disagree two, and score strongly disagree 1 . Before the questionnaire was distributed to students and teachers, two science experts carried out the construct validation. If the two science experts have declared the instrument valid, then the instrument can be used by the survey.

After scoring by the validator, these results were analyzed using descriptive statistics to obtain the average score of indicators. The increasing need for developing problem-solving-based learning videos to practice students' understanding of concepts is shown in Table.

Table 2. Analysis of Needs Categories

\begin{tabular}{cccc}
\hline No & Range Average Score & Categories & Decision \\
\hline 1 & $>3,25-4$ & Very High & Need \\
\hline 2 & $>2,5-\leq 3,25$ & High & Need \\
\hline 3 & $>1,75-\leq 2,5$ & Low & No Need \\
\hline
\end{tabular}




\begin{tabular}{lll}
\hline 4 & $1-\leq 1,75$ & Very Low \\
\hline Sumber : (Afni \& Kazmi, 2019) & & No Need
\end{tabular}

\section{RESULTS AND DISCUSSION}

The need analysis in learning that should be fulfilled in order that the learning process to run well is learning problem analysis, learner analysis, analysis of learning objectives, and analysis of learning settings. Based on the four analyzes of learning needs, it can be analyzed the level of need for developing problem-solving based learning videos in the learning process so that they can be a solution in meeting the needs of learning science.

Based on the data analysis carried out in this study, information was obtained about the students' needs for problem-solving-based learning videos for each of the needs analysis indicators. The results of data processing are shown in Figure 2 below:

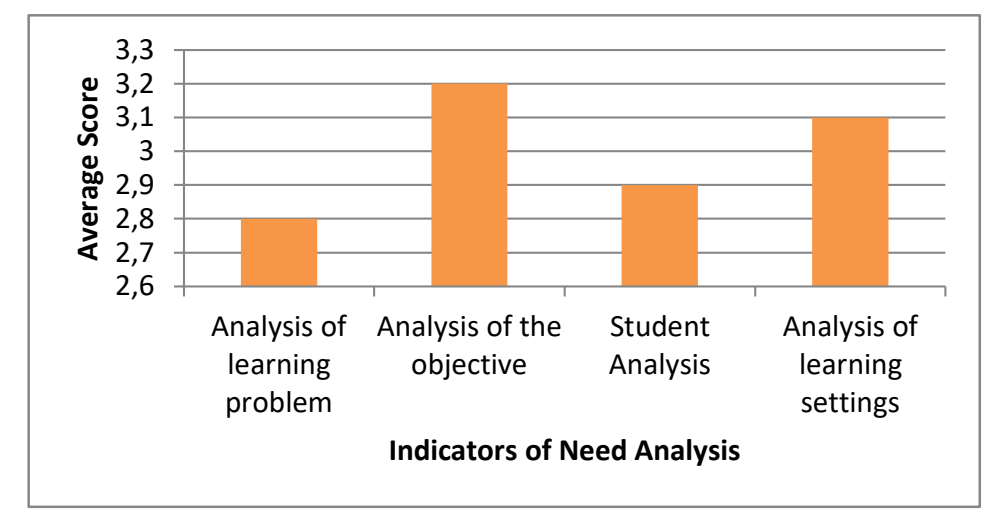

Figure 2. Results of Student Needs Analysis of Problem Solving Based Learning Videos

Problem-solving in learning is one form of learning necessity. This is stated by Asrizal et al. (2017) in their research that it is essential to make efforts to solve learning problems so that there are no gaps in learning. Based on Figure 2 above, it can be seen that the average score range for the four indicators lies between 2.5-3.2. This means that students agree with a positive statement about the development of problem-solving-based learning videos in Pekanbaru.

One of the question items approved by students in analyzing learning problems is that students who are not interested in learning only listen. However, students want to be actively involved in the learning process; students do not want to write and listen (Ucak, 2019). In addition, students also agree with the question; they are not interested in learning is only a theoretical explanation without any problem-solving activities. Some students prefer to find and solve a problem independently (Prastiwi \& Nurita, 2016).

Media also affects student motivation to learn. This can be seen in a positive statement that they prefer learning to use media that displays animation, images, and audio, such as learning videos. Supported by Ziden \& Abdul (2013), videos can help students in the learning process. They can improve student learning outcomes and motivation and have a positive impact on student understanding. In line with the opinion of Istiqomah et al. (2017), Ula et al. (2015), Yulisa et al. (2020), Learning videos can improve students' understanding of concepts. This is because the advantages possessed by video media are that it can visualize concepts more efficiently Gowasa et al., (2019) more strategic and adaptive (Seo et al., 2021).

Furthermore, the analysis of learning objectives needs to be done early before designing instructional media. This stage is carried out to determine the learning objectives to be achieved. In particular, the analysis of learning objectives is to determine the objectives of the learning orientation in terms of concepts, procedures, and theories (Peniati et al., 2013). The main hope of 
learning science is to create students who are active in building their knowledge and can use their reasoning in understanding and solving the problems at hand. (Kemendikbud, 2018). Based on Figure 2, it can be seen that this indicator obtained a score of 3.2, which means that students agree with the positive questions given. One of them, students feel that learning by finding a solution to a problem can build their knowledge. Students also agree that if learning begins with giving a problem, students look for solutions to the problem. Learning by solving problems like this is believed to make students better understand the concepts that are being studied (Ali et al., 2010).

The need analysis of learners is critical in the learning process. This is because in realizing the objectives of learning science, it is essential to analyze the learning components suitable for students so that students are in the learning process and have abilities that are by the achievement of learning objectives. Good assessment refers to the cognitive realm and needs an assessment that can measure students' skills (Widiana, 2016). The learner analysis that must be carried out in learning, namely learning, must create active students to solve problems using teachers utilizing existing technology (Yunita \& Wijayanti, 2017). One of the questions on this analysis is that students are more active in participating in learning activities if the teacher provides videos in the form of animation, text, images, and audio in the problem-solving process.

In addition to the use of video, learning must also develop students accustomed to answering problems that are not routinely done to understand concepts. Students 'understanding of concepts increases when students' reasoning abilities increase (Sadiqin et al., 2017). This is in line with the statement about learning by finding out for yourself the solution to a problem will train students' ability to reason. Students agree with this statement; this is proven by obtaining a score of 2.9, which is in the score range $>2.5-3.25$. This means that students agree with problem-solving-based learning videos that can meet the needs analysis of learners to understand learning well.

The following needs analysis is the analysis of learning settings. Based on the graph above, it can be seen that the average score range answered by students is $>2.5-3.25$. This means that students agree with a positive statement about the development of problem-solvingbased learning videos. Positive questions agreed upon by students, namely the use of models that emphasize learning that lead students to find solutions to problems, made me more challenged and motivated to learn and made students more independent. Relevant to the implementation of curriculum 2013, learning emphasizes using a learning model that is challenging and motivating so that students actively seek information (Kemendikbud RI, 2014).

Furthermore, the results of the data analysis of the distribution of questionnaires to 10 MGMP IPA teachers in the city of Pekanbaru can be seen in Figure 3 below:

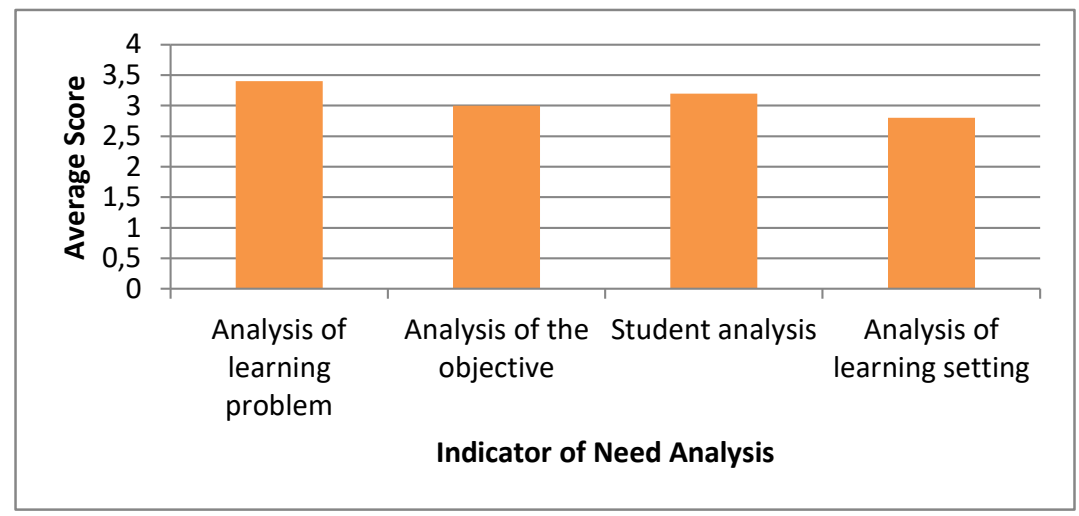

Figure 3. Results of the Teacher Needs Analysis of the Problem Solving Based Learning Videos 
Based on Figure 3, it can be seen that the level of teacher requirements for developing problem-solving-based learning videos is in the range of average scores of 2.8-3.4. This data shows that the teacher agrees with the positive statements outlined in the questionnaire items of problem solving-based learning video needs that have been distributed. In schools, teachers are one of the main determining factors in improving the quality of education through the learning process (Suwardi \& Farnisa, 2018). Teachers must participate in helping to solve learning problems that occur to get the right solution so that the solution has a positive impact on improving student abilities (Saharuddin \& Wahab, 2019).

The results of the analysis of the learning problem indicators obtained an average score of 3.4, which is in the range of scores $>3.25-4$, which means that one of the indicators of learning problem items that have been described is that students are not interested in learning that does not include their participation. The teacher gave a positive response regarding this statement. This means that student-centered learning must be created in the learning process. Supported by Sugandi (2016), which states that the science learning process must be studentcentered, which refers to the constructivist view, which can be stated that students as learning subjects can develop according to their abilities. Thus, in the science learning process, not only by transferring knowledge but also having to build a discovery process that involves the active role of students to get concepts in-depth, not just memorizing (Richards, 2020).

Furthermore, the teacher also agrees with the learning statement that is interesting for students is learning in which there are problem-solving activities. Active student involvement in problem-solving can be increased using a problem-solving model. This model is believed to train students to construct knowledge independently and is the key to successful student achievement (Gupta et al., 2016).

According to the teacher's view, students are also interested and more motivated when learning is done using videos. Video is an audio-visual medium that can improve students' problem-solving skills. This is in line with Sugandi's (2016) opinion that assisted by audio-visual media in the teaching and learning process can affect technological progress, which results in changes in teaching and learning methods; besides that, it can also improve students' problemsolving abilities. Increasing students 'problem-solving abilities will positively impact increasing students' conceptual understanding (Sadiqin et al., 2017).

Then the analysis of the learning objectives obtained an average score of 3.0, where this score is in the range $>2.5-3.25$. This means that the average teacher agrees with the positive statements on the items outlined in the questionnaire. One of the statement items for this indicator is that the teacher agrees that learning should encourage students to find and solve a problem independently. Following KI (Core Competency) 4, namely in science learning, students must be able to try, process, and present in the concrete realm according to what is being learned to solve problems (Kemendikbud, 2018).

The main hope in learning science is that students are active in building their knowledge and can use their reasoning in understanding and solving the problems at hand (Kemendikbud, 2018). However, in reality, the current learning is still not optimal because the teacher is still an active subject of learning compared to students. This is evidenced by the negative response given by the teacher to the statement item that the learning being carried out at this time has been able to make students active in building their knowledge.

The following analysis is the analysis of the learner's problem. This analysis aims to determine the problems experienced by students in carrying out learning activities according to the teacher's opinion. According to the teacher, students still have difficulty understanding a material concept. This is because students can only solve problems that are already known or routine problems and are not accustomed to answering questions that are not routine. Students find it challenging to find solutions to new problems (Wasis, 2015). They were strengthened by the results obtained an average score of 3.2. This score shows that the teacher agrees with the positive statement that the student is still not fully able to solve the new problem. Students have https://jurnal.unimus.ac.id/index.php/JPKIMIA/index 
not been able to solve problems using previous knowledge, so that it can be said that students' understanding of concepts is still low.

Finally, in this analysis, the learning setting analysis obtained an average score of 2.8 , which is interpreted, is in the range $>2.5-3.25$ with a high category, and improvement is needed in the science learning setting. The implementation of curriculum 2013 learning emphasizes interactive, inspirational, fun, challenging learning models, motivating students to actively seek information in solving problems (Kemendikbud, 2018). The problem-solving model is a model that challenges and makes students independent in solving problems (Triyuni, 2016). However, the problem-solving model is still challenging to apply in the learning process. This statement is reinforced by the opinion of the teacher, who gave a positive response to the statement. The teacher also has problems presenting learning media that encourages students to seek information in problem-solving activities. That way, media is needed to guide students in solving problems, namely problem-solving-based learning videos. Videos like this are essential to create so that the learning process is student-centered (Hamza \& Griffith, 2006). So that based on the overall analysis, students and teachers need problem-solving-based learning videos to train students' conceptual understanding in science learning.

\section{CONCLUSION}

The need analysis for developing problem-solving learning videos is based on four indicators: learning problem analysis, objective analysis, student analysis, and learning-setting analysis. Based on the overall analysis of these four indicators, it can be concluded that students and teachers in science learning need the development of problem-solving learning videos to practice concept understanding.

\section{ACKNOWLEDGMENT}

Thanks are extended to all schools that allowed the distribution of the questionnaire to be carried out. The author also thanks to the entire team of lecturers and students of the Master of Science education study program, University of Riau.

\section{REFERENCES}

Afni, N., \& Kazmi, T. (2019). The Need Analysis Developing STEM Embedded Project. Proceeding of the SS9, (1), 978-979.

Ali, R., Hukamdad, D., Akhter, A., \& Khan, A. (2010). Effect of Using Problem Solving Method in Teaching Mathematics on the Achievement of Mathematics Students. Asian Social Science. https://doi.org/10.5539/ass.v6n2p67

Asrizal, A., Festiyed, F., \& Sumarmin, R. (2017). Analisis Kebutuhan Pengembangan Bahan Ajar IPA Terpadu Bermuatan Literasi Era Digital untuk Pembelajaran Siswa SMP Kelas VIII. Jurnal Eksakta Pendidikan (Jep), 1(1), 1. https://doi.org/10.24036/jep/vol1-iss1/27

Azizah, R., Yuliati, L., \& Latifah, E. (2015). The Physic Problem Solving Difficulties on High School Student. Jurnal Penelitian Fisika Dan Aplikasinya (JPFA).

Balta, N., Mason, A. J., \& Singh, C. (2016). Surveying Turkish High School And University Students' Attitudes And Approaches To Physics Problem Solving. Physical Review Physics Education Research. https://doi.org/10.1103/PhysRevPhysEducRes.12.010129

Busyaeri, A., Udin, T., \& Zaenudin, A. (2016). Pengaruh Penggunaan Video Pembelajaran Terhadap Peningkatan Hasil Belajar Mapel IPA Di MIN Kroya Cirebon. Al Ibtida: Jurnal Pendidikan Guru MI. https://doi.org/10.24235/al.ibtida.snj.v3i1.584

Chen, C. M., \& Wu, C. H. (2015). Effects of Different Video Lecture Types On Sustained Attention, Emotion, Cognitive Load, And Learning Performance. Computers and Education. https://doi.org/10.1016/j.compedu.2014.08.015

Fitria, T., Jatmiko, B., \& Supardi, Z. A. I. (2017). Dampak Perangkat Pembelajaran IPA Pendekatan Saintifik dengan Model Problem Solving Terhadap Hasil Belajar Siswa SMP 
pada Materi Suhu dan Kalor. JPPS (Jurnal Penelitian Pendidikan Sains). https://doi.org/10.26740/jpps.v6n1.p1159-1166

Giannakos, M. N., Chorianopoulos, K., \& Chrisochoides, N. (2015). Making Sense Of Video Analytics: Lessons Learned From Clickstream Interactions, Attitudes, and Learning Outcome in A Video-Assisted Course. International Review of Research in Open and Distance Learning, 16(1), 260-283. https://doi.org/10.19173/irrodl.v16i1.1976

Gowasa, S., Harahap, F., \& Suyanti, R. D. (2019). Perbedaan Penggunaan Media Powerpoint dan Video Pembelajaran terhadap Kemampuan Berpikir Tingkat Tinggi dan Retensi Memori Siswa pada Mata Pelajaran IPA di Kelas V SD. Jurnal Tematik.

Gupta, M., K., \& Pasrija, P. (2016). Problem Solving Ability \& Locality as The Influential Factors of Academic Achievement Among High School Students. Issues and Ideas in Education. https://doi.org/10.15415/iie.2016.41004

Hamza, M., \& Griffith, K. (2006). Fostering Problem-Solving and Creative Thinking in The Classroom: Cultivating a Creative Mind. National Forum of Applied Educational Research Journal-Electronic, 19(3),1-30.

Haryadi, R., Vita, M., Utami, I. S., Ihsanudin, I., Setiani, Y., \& Suherman, A. (2019). Briquettes production as teaching aids physics for improving science process skills. Journal of Physics: Conference Series, 1157(3). https://doi.org/10.1088/1742-6596/1157/3/032006

Istiqomah, P., Werdhiana, I. K., \& Wahyono, U. (2017). Pengaruh Penggunaan Media Video Terhadap Peningkatan Pemahaman Konsep Suhu dan Kalor Pada Siswa Kelas X Man 1 Palu. JPFT (Jurnal Pendidikan Fisika Tadulako Online). https://doi.org/10.22487/j25805924.2017.v5.i3.8868

Kemendikbud. (2018). Permendikbud 37 tahun 2018. Jakarta, 40-41.

Kemendikbud RI. (2014). Permendikbud Nomor 81 A 2013. Implementasi Kurikulum Kurikulum, 1, 1-97.

Khairani, M., Sutisna, S., \& Suyanto, S. (2019). Studi Meta-Analisis Pengaruh Video Pembelajaran Terhadap Hasil Belajar Peserta Didik. Jurnal Biolokus. https://doi.org/10.30821/biolokus.v2i1.442

Ljubojevic, M., Vaskovic, V., Stankovic, S., \& Vaskovic, J. (2014). Using supplementary video in multimedia instruction as a teaching tool to increase learning efficiency and quality of experience. International Review of Research in Open and Distance Learning, 15(3), 275291. https://doi.org/10.19173/irrodl.v15i3.1825

Nizam. (2016). Ringkasan Hasil-hasil Asesmen Belajar Dari Hasil UN, PISA, TIMSS, INAP. In Seminar Puspendik 2016.

Nurdin, E., Ma'aruf, A., Amir, Z., Risnawati, R., Noviarni, N., \& Azmi, M. P. (2019). Pemanfaatan video pembelajaran berbasis Geogebra untuk meningkatkan kemampuan pemahaman konsep matematis siswa SMK. Jurnal Riset Pendidikan Matematika. https://doi.org/10.21831/jrpm.v6i1.18421

Orcos Palma, L., Blázquez Tobías, P. J., Curto Prieto, M., Molina León, F. J., \& Magreñán Ruiz, Á. A. (2018). Use of Kahoot and EdPuzzle by smartphone in the classroom: the design of a methodological proposal. Communications in Computer and Information Science. https://doi.org/10.1007/978-3-319-95522-3_4

Ozturk, T., \& Guven, B. (2016). Evaluating students' beliefs in the problem-solving process: A case study. Eurasia Journal of Mathematics, Science and Technology Education. https://doi.org/10.12973/eurasia.2016.1208a

Peniati, E., Parmin, \& Purwantoyo, E. (2013). Model analisis evaluasi diri untuk mengembangkan kemampuan mahasiswa calon guru ipa dalam merancang pengembangan laboratorium di sekolah. Jurnal Pendidikan IPA Indonesia. https://doi.org/10.15294/jpii.v2i2.2711

Pradipta, P., Sutarto, S., \& Ghani, A. (2016). Media Video Kejadian Fisika di Lingkungan Disertai Besaran Fisis dalam Pembelajaran Fisika di SMA (Studi Pada Kelas X SMA https://jurnal.unimus.ac.id/index.php/JPKIMIA/index 
Negeri 1 Muncar). Jurnal Pembelajaran Fisika, 4(4), 331-337-337.

Prastiwi, M. D., \& Nurita, T. (2016). Kemampuan Pemecahan Masalah Pada Siswa Kelas VII SMP. Jurnal Pensa, 06(02), 98-103.

Richards, A. (2020). Teaching Electricity and Magnetism Using Kinesthetic Learning Activities. The Physics Teacher, 58(8), 572-576. https://doi.org/10.1119/10.0002380

Sadiqin, I. K., Santoso, U. T., \& Sholahuddin, A. (2017a). Pemahaman konsep IPA siswa SMP melalui pembelajaran problem solving pada topik perubahan benda-benda di sekitar kita. Jurnal Inovasi Pendidikan IPA. https://doi.org/10.21831/jipi.v3i1.12554

Sadiqin, I. K., Santoso, U. T., \& Sholahuddin, A. (2017b). Students' Difficulties on Science Learning with Prototype Problem-Solving Based Teaching and Learning Material: A Study Evaluation of Development Research. 100, 279-282. https://doi.org/10.2991/seadric17.2017.58

Saharuddin, S., \& Wahab, M. (2019). Analisis Kesulitan Dalam Pemebelajaran Ipa Di Smp Negeri Limboro. Jurnal IPA Terpadu. https://doi.org/10.35580/ipaterpadu.v2i2.11148

Seo, Kyoungwon., Samuel Dodson., Negar M.Harandi., Nathan Roberson., Sidney Fels., dan I. (2021). Active learning with online video: The impact of learning context on engagement. Elsevier Ltd. 104132. https://doi.org/https://doi.org/10.1016/j.compedu.2021.104132.

Sugandi, M. (2016). Peningkatan Kemampuan Memecahkan Masalah Siswa Pada Konsep Ekosistem Dengan Pembelajaran Guided Inquiry Berbantuan Audio Visual Di Kelas VII SMP IT Hafifudin Arrohimah. Bio Educatio.

Suwardi, I., \& Farnisa, R. (2018). Hubungan Peran Guru Dalam Proses Pembelajaran Terhadap Prestasi Belajar Siswa. Jurnal Gentala Pendidikan Dasar. https://doi.org/10.22437/gentala.v3i2.6758

Tageh \& Made. 2014. Model Penelitian Pengembangan. Graha Ilmu. Yogyakarta.

Triyuni, T. (2016). The influence of science learning set using scientific approach and problemsolving model on learning outcomes of junior high school students in heat and temperature. Jurnal Pendidikan IPA Indonesia. https://doi.org/10.15294/jpii.v5i2.7679

Ucak, E. (2019). "Science Teaching and Science Teachers" from Students' Point of View. International Journal of Educational Methodology, 5(2), 221-233. https://doi.org/10.12973/ijem.5.1.221

Ula, I. R., Sutikno, \& Masturi. (2015). Video Terjadinya Petir Sebagai Media Pembelajaran Fisika Untuk Meningkatkan Pemahaman Konsep Siswa pada Materi Listrik Statis. Prosiding Seminar Nasional Fisika (E-Journal), IV, 141-144.

Wasis. (2015). Hasil Pembelajaran Sains di Indonesia: Problem dan Upaya Mengatasinya. Prosiding Seminar Nasional Pendidikan Sains yang Diseleranggara oleh Pascasarjana Unesa Tanggal 24 Januari 2015.

Whyte, S. (2017). Understanding and enriching problem solving in primary mathematics. Education 3-13. https://doi.org/10.1080/03004279.2015.1068823

Widiana, I. W. (2016). Pengembangan Asesmen Proyek Dalam Pembelajaran IPA Di Sekolah Dasar. JPI (Jurnal Pendidikan Indonesia). https://doi.org/10.23887/jpi-undiksha.v5i2.8154

Widodo, S., \& Wahyudin. (2018). Selection of Learning Media Mathematics for Junior School Students. Turkish Online Journal of Educational Technology - TOJET.

Woolfitt, Z. (2015). The effective use of video in higher education. Lectoraat Teaching, Learning and Technology. Inholland University of Applied Sciences.

Yuli Belfali. (2019). Programme for International Student Assessment (PISA) 2018 Result Indonesia. In OECD 2019.

Yulisa, Y., Hakim, L., \& Lia, L. (2020). Pengaruh Video Pembelajaran Fisika Terhadap Pemahaman Konsep Siswa Smp. Jurnal Luminous: Riset Ilmiah Pendidikan Fisika, 1(1), 37. https://doi.org/10.31851/luminous.v1i1.3445

Yunita, D., \& Wijayanti, A. (2017). Pengaruh Media Video Pembelajaran Terhadap Hasil Belajar IPA Ditinjau Dari Keaktifan Siswa. Sosiohumaniora: Jurnal Ilmiah Ilmu Sosial https://jurnal.unimus.ac.id/index.php/JPKIMIA/index 
Jurnal Pendidikan Sains (JPS). Vol. 9(1) pp 81-90 ISSN:2339-0786

DOI: https://doi.org/10.26714/jps.9.1.2021.81-90

Dan Humaniora. https://doi.org/10.30738/sosio.v3i2.1614

Zain, S. F. H. S., Rasidi, F. E. M., \& Abidin, I. I. Z. (2012). Student-Centred Learning In Mathematics Constructivism In The Classroom. Journal of International Education Research (JIER). https://doi.org/10.19030/jier.v8i4.7277

Ziden, A. A., \& Abdul Rahman, M. F. (2013). The effectiveness of web-based multimedia applications simulation in teaching and learning. International Journal of Instruction. 